\title{
Development of Foxp3+ regulatory T cell: epigenetics and more...
}

Jochen Hühn

From 6th European Workshop on Immune-Mediated Inflammatory Diseases

Nice, France. 23-25 November 2011

\section{Abstract not submitted for publication}

Published: 23 November 2011

doi:10.1186/1479-5876-9-S2-14

Cite this article as: Hühn: Development of Foxp3+ regulatory T cell:

epigenetics and more.... Journal of Translational Medicine 2011 9(Suppl 2):14.

Submit your next manuscript to BioMed Central and take full advantage of:

- Convenient online submission

- Thorough peer review

- No space constraints or color figure charges

- Immediate publication on acceptance

- Inclusion in PubMed, CAS, Scopus and Google Scholar

- Research which is freely available for redistribution

Submit your manuscript at www.biomedcentral.com/submit

\section{() Biomed Central}

